\title{
On-line vs. Face-to-Face Delivery of Information Technology Courses: Students' Assessment
}

\author{
Hazem Said, Lauren Kirgis, Brian Verkamp, and \\ Lawrence Johnson \\ University of Cincinnati, Cincinnati, $\mathrm{OH}, \mathrm{USA}$
}

\section{Hazem.Said@uc.edu Lauren.Kirgis@uc.edu Brian.Verkamp@uc.edu Lawrence.Johnson@uc.edu}

\begin{abstract}
This paper investigates students' assessment of on-line vs face-to-face delivery of lecture-based information technology courses. The study used end-of-course surveys to examine students' ratings of five course quality indicators: Course Organization, Assessment and Grading Procedures, Instructor Performance, Positive Learning Experience, and Perceived Success. The study analyzed five semesters of students' ratings and found no significant differences in the overall ratings of the course quality indicators between the on-line and face-to-face courses. There were differences between the overall ratings of the course quality indicators, with instructor performance and course organization receiving the highest ratings. More importantly, there was a significant interaction between the course quality indicators and the course structure. Examination of this interaction indicated that the course organization, the assessment and grading procedures, and the students' perceived success in the course, were higher in on-line courses, while instructor performance was better in face-to-face courses. These findings suggest different ways to improve both the on-line and face-to-face courses. Finally, the most surprising outcome was that students perceived greater success in on-line courses. However, this result needs further exploration in future studies.
\end{abstract}

Keywords: Information technology, curriculum, online vs face-to-face, students' assessment, students' success factors

\section{Introduction}

Over the last two decades, the discipline of Information Technology (IT) has emerged as a distinct program of study within the spectrum of computing education. Over this period, we have

Material published as part of this publication, either on-line or in print, is copyrighted by the Informing Science Institute. Permission to make digital or paper copy of part or all of these works for personal or classroom use is granted without fee provided that the copies are not made or distributed for profit or commercial advantage AND that copies 1) bear this notice in full and 2) give the full citation on the first page. It is permissible to abstract these works so long as credit is given. To copy in all other cases or to republish or to post on a server or to redistribute to lists requires specific permission and payment of a fee. Contact Publisher@InformingScience.org to request redistribution permission. seen a dramatic growth in IT programs in the United States and around the world. To ensure the quality of these IT programs, the Computing Accreditation Commission of ABET - the recognized US accreditation agency for college and university programs in computing - established accreditation criteria for IT programs and accredited the first three IT programs in 2006 (Gowan \& Reichgelt, 2010). At the end of 2014, there were 28 accredited programs in the US and 37 
worldwide (ABET, n.d.). IT curricula are distinguished by their need to provide hands-on instructional activities, problem solving and user-centered communication (Gowan \& Reichgelt, 2010). Courses in a typical IT curriculum include lab-based courses that focus on hands-on lab activities and lecture-based courses that do not have such lab activities. As a new field, it is critical that we gain a better understanding of the appropriate pedagogical strategies to effectively transmit essential IT concepts and skills to students. While this literature is still emerging, there are some suggested practices that highlight the importance of factors such as instructor performance, class organization, grading procedures, course content, students' motivation and the students' behavior related to the course (Zhang \& Aasheim, 2011).

Adding to the challenges of providing effective instruction within the different IT programs is the emerging pressure to provide on-line instruction. Institutions and students alike are demanding the availability of on-line delivery options (Allen \& Seaman, 2013; Mayadas, Bourne, \& Bacsich, 2009; Murray, Perez, Geist, \& Hedrick, 2012). Given the rising cost of higher education, it is likely that there will be a growing increase in the number of students that must work while taking classes (Fain, 2010), especially among non-traditional students. In addition, more traditional students are signing up for on-line classes. A 2013 survey of 2800 colleges and universities found that 7.1 million students $(33.5 \%)$ were taking at least one online course, which was the highest percentage to be recorded in the survey's eleven-year history (Allen \& Seaman, 2013).

Like other disciplines within academia, IT will have to make the modifications needed to address this increasing demand for on-line courses and to research the best pedagogical practices to maintain program quality. We cannot assume that the same practices that work in a traditional classroom will be effective in an on-line class. In addition to the emerging body of research related to the quality of IT instruction, there is existing research related to instruction quality in general that we can apply to IT. In an attempt to expand the research base for quality IT programs, we identified the following research questions:

1. Is there any difference in students' overall course quality ratings for face-to-face vs online courses?

2. Is there any difference in students' perception of the individual course quality factors between face-to-face and on-line courses?

3. Is there a differential effect between the course structure (face-to-face vs online) and the rating of individual course quality factors?

The lecture-based courses in an IT curriculum are different in nature from the lab-based courses. This study will focus on lecture-based courses and future work will study IT courses that include a significant lab component.

\section{Literature Review}

The Computing Accreditation Commission of ABET approved accreditation criteria for Information Technology programs in 2006 (ABET, n.d.; Gowan \& Reichgelt, 2010). Accreditation standards provide programs with a set of criteria that ensures the continued quality of the program. In addition to the accreditation criteria, a model curriculum for IT programs was published in 2008 that reflected the continued partnership of academia and industry to ensure the quality of IT programs (Ekstrom et al., 2005; Lunt, Lawson, Goodman, \& Helps, 2002; Reichgelt et al., 2004). IT programs continue to experience growth in enrollment in response to the continued penetration of communication and information technologies in all sectors of society and the growing needs for qualified professionals to help users and organizations utilize these technologies. 
This literature review is divided into three sections. The first section reviews the different types of courses that typically exist in IT programs and the impact of course activities on the course structure. The second section reviews diverse studies that examine how the course activities in traditional and on-line courses can influence students' learning. The third and final section looks into literature on the factors that impact course quality.

\section{Lab-based vs Lecture-based Courses}

Courses in IT programs are distinguished from other computing disciplines by requiring a higher level of technical expertise (Gowan \& Reichgelt, 2010). In addition, IT professionals assume a more proactive role with users, which requires service orientation to be covered in IT curricula (Gowan \& Reichgelt, 2010). Typical IT curricula will include courses that emphasize hands-on practice as well as courses that emphasize concepts and theory.

Lab-based courses are common in IT programs. These are courses that have a high level of technology skills development and a requirement for hands-on practice; for instance, learning how to write computer programs, or how to administer an active directory server. On the other hand, lecture-based courses do not have hands-on practice requirement and include activities such as reading and writing papers, sitting for exams and engaging in discussion; for example, courses such as the implications of using information technology, the management of information technology, fundamental concepts of IT, or information assurance and security. The activities and students' learning are different between lab-based and lecture-based courses.

Research suggests that the nature of the course activities may play a role in the quality of on-line vs face-to-face instruction. Webb, Gill, and Poe (2005) found that students' learning improved when applying the case method pedagogy using a web-based discussion tool. Hansen (2008) suggested that on-line instruction may not be suitable for all courses, but found that courses that involved students working in groups to apply theory had a better outcome in on-line structure than in face-to-face structure. Burns, Duncan, Sweeney, North, and Ellegood (2013) reached a different conclusion in an introductory information systems course where they found that students performed better in face-to-face courses than online courses. On the other hand, Wagner, Garippo, and Lovaas (2011) studied introductory business applications courses taught by the same instructor over a ten year period and found no statisically signficant difference between online and face-to-face courses. Friday, Friday-Stroud, Green, and Hill (2006) reached a similar conclusion when teaching two management courses over eight semseters both on-line and faceto-face.

Several studies reviewed by Weber and Lennon (2007) showed mixed results in students' performance and satisfaction across different courses and disciplines. Some studies found on-line courses to be superior, others found face-to-face courses to be superior, while the majority of studies found no difference in learning outcomes or students' satisfaction between the two course delivery modes. These studies spanned subject areas in marketing, management, introductory information systems, nursing, nutrition, and education. Some studies compared graduate courses while others compared undergraduate courses.

The next section reviews studies that looked specifically at IT courses and examined the use of technology to support learning as well as the use of online activities to enable and supplement face-to-face learning.

\section{On-line vs Face-to-Face Instruction for IT Courses}

A review of the literature reveals that diverse studies have explored how the teaching methods used in traditional and on-line courses can influence student learning. 
Lim (2007) found that synchronous on-line tutoring environments used in an undergraduate IT course provided the social, teaching, and cognitive elements necessary for a successful higher education experience. Furthermore, $\mathrm{Ng}$ (2007) recognized that for effective on-line interaction between tutors and students, the technology tool should have low overhead in terms of the learning curve and the limitations on student-student interaction as well as student-tutor interaction. A study by Carver, Todd, Hahn, and Mukherjee (2013) found that the implementation of a synchronous interactive online tool by itself did not have a significant effect on students' learning. They found that the way the online tool is implemented is what made the difference. For instance, when a synchronous interactive online tool was used to provide instructions related to students' assignments, the students became more confident, gained better understanding of the content and learned to apply the course concepts to solve problems (Carver et al., 2013).

A study by Condon and Valverde (2014) noted that IT students' responses to discussion questions in an on-line non-IT course tend to lack original content compared to what is usually found in traditional face-to-face discussion. They examined ways to increase the achievement of the learning objectives and critical thinking in asynchronous on-line class forums. They found that providing clear guidelines to students on what is expected in an essay response to a discussion question, developing clear grading rubrics that reflect those guidelines, and providing samples to students, improved the originality of student content and the utilization of their critical thinking skills.

Trevathan and Myers (2013) examined the implementation of the Process-Oriented Guided Inquiry learning technique in on-line IT courses. Earlier studies in traditional classroom lectures showed that this technique improved students' problem solving abilities, interpersonal skills and learning outcomes, which encouraged them to examine the implementation in an on-line environment. The incorporation of wikis, blogs and Facebook into the learning management system was viewed favorably by both teachers and students in increasing engagement and supporting group work.

Murray et al. (2012) examined patterns of student access to course material in an on-line IT/digital literacy course environment. They found that the more resources a student interacts with, the greater chance they have of achieving a higher level of success in the course. In their study, students reported a tendency to retrieve only content that they perceive to be necessary to complete course deliverables directly tied to course assessment. Furthermore, they found that students are less likely to engage with course materials that they perceive to be ancillary or secondary.

The capstone project is an important component of most IT programs. It could be challenging for students to complete the capstone project in an on-line environment, especially when working in groups. Tappert and Stix (2011) implemented procedures to effectively manage geographically distributed student teams in a hybrid capstone IT course. They highlighted the importance of course organization; effective instructor-student communication and setting clear guidelines and expectations for each member of the team. This is similar to what Newman and Hermans (2008) found when forming virtual teams to work on a marketing project as part of an MBA graduate course in marketing.

Although on-line learning environments differ from face-to-face environments, it is possible to achieve the same quality of instruction if relevant factors that impact the quality of the course and the students' learning are considered and implemented. Nevertheless, different course structures (face-to-face, on-line or hybrid) do have an impact on the quality of learning. Moreover, lecturebased and lab-based courses include different learning activities and may need different pedagogical approaches. Simonson, Schlosser, and Hansen (1999) theorized that providing students with equivalent learning experiences is the key to achieving similar outcomes for different course structures. Lapsley, Kulik, Moody, and Arbaugh (2008) investigated the validity of this theory by 
comparing on-line and face-to-face course structures for a senior level human resource management course, and concluded that online learning may even be superior in its overall effect on students' performance.

\section{Academic Success Factors}

Senn (2008) studied the transition of a course with a high level of technology skills development and a significant requirement for hands-on practice, from face-to-face format to on-line format. He found that significant effort by the instructor was necessary for successful transition of the course. Furthermore, he found that the students perceived that participating in the hybrid course format with fewer face-to-face meetings increased the amount of work they needed to do for the course. Herman and Banister (2007), on the other hand, found that clearly articulated expectations and instructions provided by the instructor had the effect of lessening anxiety and increasing students' sense of self-efficacy.

In addition to the additional instructor's effort combined with their experience and skills, the course organization and the in-study material available to students are factors that impact student learning in on-line courses (Mayadas et al., 2009). Zhang and Aasheim (2011) combined existing research on academic success factors into a cohesive framework, incorporated additional factors identified by undergraduate IT students into the framework, and then asked the students to rank the factors as they related to their academic success. The students ranked the instructor's personality, and their organizational and communication skills as the top factors that impacted their learning. In addition, the students ranked the course organization and their own self-motivation and commitment to learning as important. In another study, Bergstrand and Savage (2013) found that instructors' enthusiasm, prepardness and skills are important factors in the effectiveness of online courses. Drago, Peltier, and Sorensen (2002) confirmed this finding and found that both the instructor and the course contents are strong predictors of the effectiveness of on-line coures.

Although there is much more research needed on effective instruction for traditional and on-line information technology courses, it is not surprising that a consistent set of success factors or quality indicators is emerging. Clearly the performance of the instructor is a critical component of an effective course, as is the organization of the class and the students' own commitment. How these factors impact the students' learning, their perceived success and satisfaction with course work is important to understand. Moreover, we need to understand how these variables are impacted by the structure of the course (on-line vs face-to-face).

The success of students in IT programs is a reflection of the overall course quality. This study investigated students' perception of course quality factors in on-line vs face-to-face IT courses where teaching and learning methods were based on a traditional lecture-based approach. We hope that the research method that we developed and the results that were obtained for lecturebased courses will enable us to expand to lab-based courses in a future study.

\section{Methods}

Data for this study was obtained from 513 students enrolled in multiple sections of four courses in an undergraduate ABET-accredited bachelor degree in IT offered by a large public research university in the Midwest. The courses were administered through the Blackboard learning management system. For each course, the textbook, learning outcomes and, in many instances, the assignments were the same for both course structures (on-line or face-to-face) and across the different semesters. All instructors met annually to review the course outcomes and assignments. In many instances, instructors shared the course contents for the different sections. In the on-line sections, discussion boards, blogs, journals, asynchronous videos, and on-line synchronous sessions were used to facilitate communications between the instructor and the students. The group 
feature in the Blackboard system was used for group work. This feature provided group members with file sharing, a discussion board, journals, blogs, and other tools. In the remainder of this section we address how quality indicators were defined, how courses were selected, and how data was collected.

\section{Course Quality Indicators}

In the fall of 2012, the University switched from a quarter-based system to a semester-based system. At the end of each semester following the conversion, students were asked to complete an end-of-semester survey to evaluate the quality of instruction for each of their courses, and the resulting data were used for this study. Several studies have found that end-of-course evaluations can provide useful insight into the quality of instruction (Bergstrand \& Savage, 2013; Drago et al., 2002).

The end-of-semester survey was designed by a committee of faculty from different disciplines and was integrated into an electronic system called CourseEval. The survey asked the students to rate sixteen statements on a scale of one through five where one indicated that they strongly disagree with the statement and five indicated that they strongly agreed with the statement. Table 1 lists the different survey statements.

Table 1: End-of-course survey

\begin{tabular}{|l|}
\hline \multicolumn{1}{|c|}{ Statement } \\
\hline Given the challenges in teaching any particular class, this course met the stated course objectives. \\
\hline The textbook and/or required course materials were high quality and useful for this course. \\
\hline The course and learning activities were well organized and sequential. \\
\hline The length and content of the various course assessments were appropriate. \\
\hline The grading procedures for this course were clear and fair. \\
\hline I achieved the student outcomes for this course. \\
\hline The amount of content addressed in this course was appropriate. \\
\hline My grades in the course are an accurate reflection of my learning and effort. \\
\hline This course was a positive learning experience. \\
\hline The instructor was knowledgeable about the content of the class. \\
\hline The instructor was well prepared for each class. \\
\hline The instructor covered material at an appropriate pace. \\
\hline $\begin{array}{l}\text { The instructor provided prompt, helpful, and appropriate feedback on class work and assignments } \\
\text { in a timely fashion. }\end{array}$ \\
\hline The instructor was fair and respectful of students. \\
\hline The instructor was accessible and available during office hours. \\
\hline Working with this instructor was a positive learning experience. \\
\hline
\end{tabular}

The survey statements were organized into categories informed by the literature on course success factors such as the work of Zhang and Aasheim (2011). Table 2 defines the categories or course quality indicators that were used in the study. 
Table 2: Definition of the course quality indicators

\begin{tabular}{|l|l|}
\hline \multicolumn{1}{|c|}{ Course Quality Indicator } & \multicolumn{1}{c|}{ Definition } \\
\hline Course Organization (CO) & $\begin{array}{l}\text { The appropriateness and quality of the text, pace of instruction, appro- } \\
\text { priateness of assignments, and the breadth of content covered. }\end{array}$ \\
\hline $\begin{array}{l}\text { Assessment and Grading } \\
\text { Procedures (AGP) }\end{array}$ & $\begin{array}{l}\text { The appropriateness of assessment and grading procedures, the per- } \\
\text { ceived quality of feedback received, timeliness of feedback, perceived } \\
\text { fairness of assessment and grading procedures. }\end{array}$ \\
\hline Instructor Performance (IP) & $\begin{array}{l}\text { The perceived content knowledge of the instructor, accessibility, prepar- } \\
\text { edness, presentation quality, instructional pace, and being fair and re- } \\
\text { spectful of students. }\end{array}$ \\
\hline $\begin{array}{l}\text { Positive Learning Experience } \\
\text { (PLE) }\end{array}$ & An overall rating of the course and the instructor. \\
\hline Perceived Success (PS) & $\begin{array}{l}\text { A student self-assessment of their success in the course and if the grade } \\
\text { they received matched their assessment of their performance in the class. }\end{array}$ \\
\hline
\end{tabular}

Each course quality indicator is related to one or more survey statements as shown in Table 3.

Table 3: Course quality indictors' mapping to survey statements

\begin{tabular}{|c|c|}
\hline Course Quality Indicator & Survey Statements \\
\hline \multirow[t]{4}{*}{ Course Organization $(\mathrm{CO})$} & $\begin{array}{l}\text { Given the challenges in teaching any particular class, this course met the } \\
\text { stated course objectives. }\end{array}$ \\
\hline & $\begin{array}{l}\text { The textbook and/or required course materials were high quality and } \\
\text { useful for this course. }\end{array}$ \\
\hline & The course and learning activities were well organized and sequential. \\
\hline & The amount of content addressed in this course was appropriate. \\
\hline \multirow[t]{3}{*}{$\begin{array}{l}\text { Assessment and Grading } \\
\text { Procedures (AGP) }\end{array}$} & $\begin{array}{l}\text { The length and content of the various course assessments were appro- } \\
\text { priate. }\end{array}$ \\
\hline & The grading procedures for this course were clear and fair. \\
\hline & $\begin{array}{l}\text { The instructor provided prompt, helpful, and appropriate feedback on } \\
\text { class work and assignments in a timely fashion. }\end{array}$ \\
\hline \multirow[t]{5}{*}{ Instructor Performance (IP) } & The instructor was knowledgeable about the content of the class. \\
\hline & The instructor was well prepared for each class. \\
\hline & The instructor covered material at an appropriate pace. \\
\hline & The instructor was fair and respectful of students. \\
\hline & The instructor was accessible and available during office hours. \\
\hline \multirow{2}{*}{$\begin{array}{l}\text { Positive Learning Experience } \\
\text { (PLE) }\end{array}$} & This course was a positive learning experience. \\
\hline & Working with this instructor was a positive learning experience. \\
\hline \multirow[t]{2}{*}{ Perceived Success (PS) } & I achieved the student outcomes for this course. \\
\hline & $\begin{array}{l}\text { My grades in the course are an accurate reflection of my learning and } \\
\text { effort. }\end{array}$ \\
\hline
\end{tabular}




\section{Selection of Courses}

This study examined lecture-based IT courses where teaching and learning followed the traditional lecture style. An IT program typically includes different types of courses, mainly lecture-based and lab-based. Lecture-based courses rely more on lectures, discussions, and presentations by the students whereas lab-based courses require extensive hands-on learning, usually taking place in a lab environment or using computer tools.

The lab-based courses normally involve live demonstration of technology along with assignments where students are expected to practice and demonstrate their technical competency. These courses may cover topics such as computer programming, administration of different operating systems, digital media development, administration and development of database systems, and so on.

Activities in the lecture-based courses, however, typically include lectures, reading articles, discussion topics, written reports and presentations. The assignments in these courses are typically quizzes, exams, and papers. This study focused on lecture-based courses, while future work will examine lab-based courses.

For the purpose of this study, we chose to examine four lecture-based courses in an undergraduate ABET-accredited Bachelor of Information Technology degree. The courses were scheduled at different intervals in the degree program. Table 4 lists the courses, when they are offered in the curriculum, and their description.

Table 4: Lecture-based courses used in the study

\begin{tabular}{|l|l|l|}
\hline \multicolumn{1}{|c|}{ Course } & When offered & \multicolumn{1}{c|}{ Description } \\
\hline $\begin{array}{l}\text { Fundamentals of } \\
\text { Information } \\
\text { Technology }\end{array}$ & Freshmen & $\begin{array}{l}\text { This course is an introduction to the field of Information Tech- } \\
\text { nology including technology concepts, terminology, hardware } \\
\text { components and software applications. Students will be intro- } \\
\text { duced to and asked to apply basic skills in the core areas of in- } \\
\text { formation technology such as programming, database } \\
\text { management, networking, systems administration, and web de- } \\
\text { velopment and the basic research, problem solving and decision } \\
\text { making skills required to be successful in this field. The course } \\
\text { emphasizes the role of technical communication, project man- } \\
\text { agement, languages, tools, models and application architectures } \\
\text { within the IT development process. }\end{array}$ \\
\hline $\begin{array}{l}\text { Implications of } \\
\text { Information } \\
\text { Technology }\end{array}$ & Sophomore & $\begin{array}{l}\text { This course focuses on the impact brought upon our society by } \\
\text { computers and its related technologies. Issues related to privacy, } \\
\text { ethics, law, encryption, copyright, computer crimes, professional } \\
\text { ethics and responsibilities will be critically examined. }\end{array}$ \\
\hline $\begin{array}{l}\text { Information Se- } \\
\text { curity and As- } \\
\text { surance }\end{array}$ & $\begin{array}{l}\text { Freshmen/ } \\
\text { Sophomore }\end{array}$ & $\begin{array}{l}\text { An introduction to the various technical and administrative as- } \\
\text { pects of information security and assurance. This course provides } \\
\text { the foundation for understanding the key issues associated with } \\
\text { protecting information assets, determining the levels of protection } \\
\text { and response to security incidents, and designing a consistent, } \\
\text { reasonable information security system, with appropriate intru- } \\
\text { sion detection and reporting features. }\end{array}$ \\
\hline $\begin{array}{l}\text { Management in } \\
\text { Technology }\end{array}$ & Junior & $\begin{array}{l}\text { General management techniques and specific issues and tools for } \\
\text { project management in information technology. }\end{array}$ \\
\hline
\end{tabular}




\section{Data Collection}

The University CourseEval system administered the survey electronically at the end of each semester. Each enrolled student was emailed a link four weeks before exam week and was encouraged to complete the survey. After two weeks, an email reminder was sent to the students. Faculty members were encouraged to email students to remind them to complete the survey.

The data for this study was collected over two academic years (five semesters) starting immediately after the previous quarter-based system was converted to a semester-based system. During this period, a total of 37 course sections were taught, although not all sections were offered every semester. Table 5 shows the total number of enrolled students and the number of responses received per semester for the on-line and face-to-face course sections. Looking at the accumulated data over the five semesters, 19 sections were taught face-to-face with a total of 292 survey responses, and 18 sections were taught on-line with a total of 264 survey responses.

\section{Table 5: Data used for the study}

\begin{tabular}{|l|l|c|c|c|c|}
\hline $\begin{array}{c}\text { Academic } \\
\text { year }\end{array}$ & Semester & \multicolumn{2}{c|}{$\begin{array}{c}\text { Number of responses for } \\
\text { face-to-face sections }\end{array}$} & \multicolumn{2}{c|}{$\begin{array}{c}\text { Number responses for } \\
\text { on-line sections }\end{array}$} \\
\hline & & Enrollment & Responses & Enrollment & Responses \\
\hline $2012-2013$ & Fall & 148 & 84 & 144 & 57 \\
\hline & Spring & 64 & 33 & 182 & 64 \\
\hline $2013-2014$ & Summer & 8 & 8 & 38 & 14 \\
\hline & Fall & 188 & 112 & 155 & 81 \\
\hline & Spring & 105 & 55 & 152 & 48 \\
\hline Total & & $\mathbf{5 1 3}$ & $\mathbf{2 9 2}$ & $\mathbf{6 7 1}$ & $\mathbf{2 6 4}$ \\
\hline
\end{tabular}

\section{Results}

There are three research questions for this study related to:

1. differences between overall student ratings of the course structure (face to face courses vs on-line courses);

2. differences between overall student ratings of the five individual course quality indicators; and

3. differences in the pattern of student ratings of course quality indicators across the different course structures.

To answer these questions, the data were analyzed using a split plot factorial ANOVA, which allowed us to investigate the existence of interaction between the course quality indicators and the course structure. One between-group factor was used to determine whether there was any difference in ratings between course structures (research question 1) and one between-group factor was used to determine whether there was any difference between overall course quality indicators (research question 2) and the interaction between course structure and the five individual course quality indicators (research question 3 ). In the remainder of this section we will provide a breakdown of the mean ratings from students on the five course quality indicators across the course structure and the results of the analysis.

Table 6 provides the means of the student ratings of the course quality indicators (CQI). The Overall Mean Ratings on course quality indicators for face-to-face and online sections combined 
ranged between 4.278 and 4.427. The Combined CQI Mean Ratings for the different course structures were 4.282 for face-to-face courses and 4.351 for on-line delivery courses.

Table 6: Mean values for the Course Quality Indicators (CQI)

\begin{tabular}{|c|c|c|c|c|}
\hline \multicolumn{2}{|c|}{ Course Quality Indicators } & \multirow{2}{*}{$\begin{array}{c}\begin{array}{c}\text { Face-to-face } \\
\text { delivery }\end{array} \\
\mathbf{n}=\mathbf{2 9 2} \\
\end{array}$} & \multirow{2}{*}{$\begin{array}{c}\begin{array}{c}\text { On-line } \\
\text { delivery }\end{array} \\
\mathbf{n}=\mathbf{2 6 4} \\
\end{array}$} & \multirow{2}{*}{$\begin{array}{c}\begin{array}{c}\text { Overall } \\
\text { rating }\end{array} \\
\mathbf{n}=\mathbf{5 1 3} \\
\end{array}$} \\
\hline \multirow{3}{*}{ Course Organization (CO) } & & & & \\
\hline & Mean & 4.219 & 4.396 & 4.308 \\
\hline & $\mathrm{SD}$ & 0.315 & 0.197 & 0.256 \\
\hline \multirow{2}{*}{$\begin{array}{l}\text { Assessment and Grading Proce- } \\
\text { dures (AGP) }\end{array}$} & Mean & 4.228 & 4.328 & 4.278 \\
\hline & SD & 0.403 & 0.254 & 0.329 \\
\hline \multirow{2}{*}{ Instructor Performance (IP) } & Mean & 4.452 & 4.401 & 4.427 \\
\hline & SD & 0.302 & 0.293 & 0.298 \\
\hline \multirow{2}{*}{$\begin{array}{l}\text { Positive Learning Experience } \\
\text { (PLE) }\end{array}$} & Mean & 4.274 & 4.311 & 4.293 \\
\hline & $\mathrm{SD}$ & 0.324 & 0.295 & 0.310 \\
\hline \multirow{2}{*}{ Perceived Success (PS) } & Mean & 4.239 & 4.319 & 4.279 \\
\hline & SD & 0.358 & 0.286 & 0.322 \\
\hline \multirow{2}{*}{ Combined CQI } & Mean & 4.282 & 4.351 & 4.317 \\
\hline & SD & 0.340 & 0.265 & 0.303 \\
\hline
\end{tabular}

Using SPSS software, we analyzed these data through a split plot factorial ANOVA with one between-group factor representing the course structure (on-line delivery or face-to-face delivery) and one between-group factor representing the course quality indicators.

The first research question focused on determining if there were any differences between the overall ratings in on-line vs. face-to-face courses. As can be seen in Table 7, this analysis revealed that there were no statistically significant differences between the students' ratings across the two course structures $(\mathrm{F}=0.528, \mathrm{p}=0.472)$.

Table 7: Effect of Course Structure (on-line vs face-to-face)

\begin{tabular}{|l|c|c|c|c|c|c|}
\hline \multicolumn{1}{|c|}{ Source } & $\begin{array}{c}\text { Type III sum } \\
\text { of squares }\end{array}$ & $\begin{array}{c}\text { Degree of } \\
\text { freedom }\end{array}$ & $\begin{array}{c}\text { Mean } \\
\text { square }\end{array}$ & F & Sig. & $\begin{array}{c}\text { Partial eta } \\
\text { squared }\end{array}$ \\
\hline $\begin{array}{l}\text { Course } \\
\text { Structure }\end{array}$ & 0.218 & 1 & 0.218 & 0.528 & 0.472 & 0.015 \\
\hline Error & 14.439 & 35 & 0.413 & & & \\
\hline
\end{tabular}

In the second research question, we examined whether there were any differences in the overall ratings of the course quality indicators regardless of the course structure. The results of this analysis are shown in Table 8. As shown in the first row of Table 8 ("Course Quality Indicators"), there were significant differences in the student ratings of Course Quality Indicators $(F=9.179$, $\mathrm{p}=0.000)$. 
Table 8: Analysis of differences in Course Quality Indicators and their interaction with Course Structure

\begin{tabular}{|l|c|c|c|l|c|c|}
\hline Source & $\begin{array}{l}\text { Type III } \\
\text { sum of } \\
\text { squares }\end{array}$ & $\begin{array}{l}\text { Degree of } \\
\text { freedom }\end{array}$ & $\begin{array}{l}\text { Mean } \\
\text { square }\end{array}$ & F & Sig. & $\begin{array}{l}\text { Partial eta } \\
\text { squared }\end{array}$ \\
\hline $\begin{array}{l}\text { Course Quality } \\
\text { Indicators }\end{array}$ & 0.575 & 2.772 & 0.208 & 9.179 & 0.000 & 0.208 \\
\hline $\begin{array}{l}\text { Course Quality } \\
\text { Indicators x Course } \\
\text { Structure }\end{array}$ & 0.258 & 2.772 & 0.093 & 4.107 & 0.010 & 0.105 \\
\hline Error & 2.197 & 97.015 & 0.023 & & & \\
\hline
\end{tabular}

The third research question investigated the differential effect between the Course Structure and the Course Quality Indicators. The second row of Table 8 ("Course Quality Indicators x Course Structure") shows that there is a significant interaction between the ratings of course quality indicators and the course structure $(\mathrm{F}=4.107, \mathrm{p}=0.010)$. To further understand the differences between the Course Quality ratings and the interaction between Course Quality ratings and Course Structure, we plotted the mean ratings of the Course Quality Indicators for each Course Structure, which is presented in Figure 1.

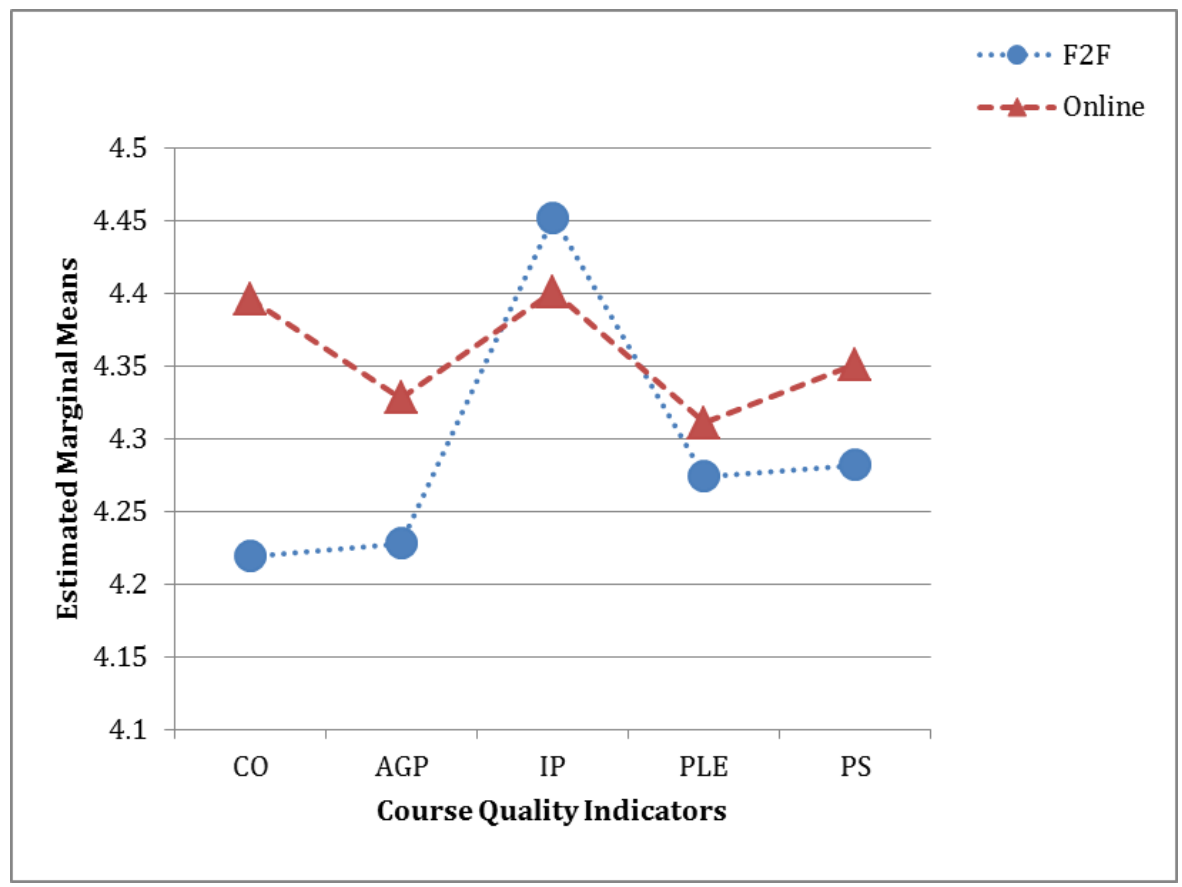

\section{Figure 1: Significance of interaction between the Course Structure and the Course Quality Indicators}

Figure 1 shows that there were very distinct differences in the students' ratings of the course quality indicators. While instructor performance was rated highly in both course delivery modes, it was much higher for students in the face-to-face classes. On the other hand, the remaining quality factors (course organization, assessment and grading procedures, perceived course success and the positive learning experience) were rated higher in on-line classes. 


\section{Discussion}

In this study we found that for lecture-based IT courses, there were no significant differences in the students' assessment of the overall course quality indicators between face-to-face and on-line courses (research question 1). This finding is consistent with a body of literature that suggested that students in on-line classes perform at the same level as those in traditional courses (Murray et al., 2012). Furthermore, on-line courses may even be superior to face-to-face courses, especially in cases where the application of theory is required (Hansen, 2008).

Analysis of this data also indicated that there was a difference in the overall ratings of the course quality indicators with instructor performance and course organization receiving the highest ratings in on-line courses while the instructor's performance was perceived to be superior in face-toface courses (research question 2). This finding confirms Zhang and Aasheim's (2011) study where students ranked instructor performance as the most important academic success factor.

However, there was a significant interaction between ratings of the course quality indicators across course structure. Instructor performance was rated highly by both groups, but it was rated much higher by students in face-to-face classes. Course organization, assessment and grading procedures, and perceived course success were rated higher in on-line courses. Student ratings regarding their perception of the courses being a positive learning experience were similar for students in both face-to-face and on-line courses. The implications of these results are discussed in the remainder of this section.

For several years, the providers of different IT programs have been debating whether or not online delivery of IT courses can enable effective learning of communication, problem solving, and hands-on skills. This study is still preliminary and follow-up work is thus needed. However, our preliminary results suggest that there is no significant difference between overall course quality ratings when a lecture-based IT course is delivered on-line or face-to-face, which supports the earlier findings of Friday et al. (2006) and Wagner et al. (2011).

When it came to rating the learning experience, the students rated the on-line and face-to-face classes as equally positive, with on-line courses having a slight edge. We deduce from this that the learning experience is not dependent on the delivery mode of the IT course. In fact, we would argue that, like any course, the key consideration is how to make the course a positive learning experience regardless of the mode of instruction. This is consistent with what Lapsley et al. (2008) found when comparing two sections of the same human resource management course. Further, the results from our study provided some guidance on how to make these courses more effective.

The course quality indicators suggest that students have different perceptions of course effectiveness depending on whether the course is an on-line course or a face-to-face course. For instance, students perceived that on-line courses display better course organization. Students' sense of selfefficacy is improved through clearly articulated expectations and instructions (Herman \& Banister, 2007). Course organization involves a combination of the choice of textbook, the organization of the learning activities, the pace of the course, and the degree to which the course meets its stated objectives. In our study, the on-line and face-to-face courses used the same textbook. While the objectives and the text were the same, students perceived the organization of the learning activities and meeting the stated objectives to work better for on-line courses than face-to-face courses. This suggests that students found the pace and organizational structure superior in online courses.

In addition, the course quality factors related to grading and assessment procedures and the students' perceived success appeared to be more effective for on-line courses. As shown in Table 2, these factors are related to the length and appropriateness of the assessment activities, the 
promptness of the instructor's feedback, the clarity of the course outcomes, and the students' confirmation that their grades are an accurate reflection of their learning for the course. This confirmed the finding of Condon and Valverde (2014) that using clear expectations and grading rubrics help increase students' utilization of critical thinking skills.

The results showed that the performance of the instructor is an important factor for both face-toface and on-line courses. However, this data clearly indicated that students rate instructors most positively in face-to-face courses. Webb et al. (2005) suggested that, in some online courses, the role of the instructor might not be as valuable, since in courses where students are focused on applying their knowledge to case studies, students in online sections act more independently and may not be as reliant on the instructor as in face-to-face courses. Bergstrand and Savage (2013) found that students feel that they receive less respect from the instructors in online courses. They suggested that the instructor's enthusiasm, preparedness, and skills are important factors in the effectiveness of online courses. In their study, students rated instructors higher in face-to-face classes than on-line classes.

Instructors are more effective when they are student centered, expert, enthusiast and ethical (Carver et al., 2013). We do believe, however, that it is the preparedness of the instructors, their respect for the students, their command of the subject matter, and their availability to the students, that make a difference. The presence of the instructor with the students in face-to-face classes may naturally provide for some of these factors. In on-line courses, instructors need to establish presence with the students. The use of synchronous interactive online tools can make a difference if used to support the course instructions (Carver et al. 2013). Adding asynchronous on-line discussion with clear protocol for communication also has a positive impact on course effectiveness (Webb et al., 2005).

\section{Conclusions}

While we acknowledge the need for further studies, we suggest that the debate on whether courses should be offered on-line or face-to-face should shift towards improving the effectiveness of the course quality indicators. What is important is how we make all courses a meaningful experience for students, regardless of the mode of instruction. This preliminary study showed that there is room for improvement for both course delivery methods. This conclusion is consistent with the equivalency theory, which suggests that learning outcomes depend on the learning experiences made available to the learners rather than on the mode of delivery alone (Simonson et al., 1999).

Instructors for on-line courses need to extend their availability and improve their communication with students. Academic departments can focus their instructors' training on the use of activities and tools that increase the level of one-on-one and group communication between instructors and students. Examples of these tools include hosting on-line office hour sessions, using recorded videos for asynchronous communication, interactive discussion boards and improving the instructors' responsiveness to students' posts and submissions (Lapsley et al., 2008).

On the other hand, face-to-face courses can benefit from enhancements to the course organization, the grading procedures, and the clarity of the outcomes. Instructors' presence in the classroom can sometimes reduce the priority given to other course quality factors such as organizing the course contents, pacing the learning and assessment activities, providing prompt written feedback to each student, and clarifying the learning outcomes throughout the semester. Historically, academic departments have given more resources to the development and organization of on-line courses. We suggest that similar attention should to be given to face-to-face courses as well.

Finally, we recognize the limitations of this study. The study considered lecture-based courses and future work should investigate lab-based courses. Although the data do provide insight into factors related to course quality, more research is needed to further explore how to improve the 
quality of IT courses. We were also surprised to see that, although students performed similarly in both face-to-face and on-line courses, students perceived that they had greater success in on-line courses. We intend to explore this finding further by examining the students' comments recorded in the surveys. A more qualitative approach may give us a deeper understanding as to why students perceived the course quality factors differently in these two modes of instruction, as well as why they felt more successful in on-line courses.

\section{References}

ABET (n.d.). Find accredited programs. The Accreditation Board of Engineering Technology. Retrieved from http://main.abet.org/aps/Accreditedprogramsearch.aspx

Allen, E. I., \& Seaman, J. (2013). Grade change: Tracking online education in the United States. Babson Survey Research Group.

Bergstrand, K., \& Savage, S. V. (2013). The chalkboard versus the avatar: Comparing the effectiveness of online and inclass courses. Teaching Sociology, 41(3), 294-306.

Burns, K., Duncan, M., Sweeney II, D. C., North, J. W., \& Ellegood, W. A. (2013). A longitudinal comparison of course delivery modes of an introductory information systems course and their impact on a subsequent information systems course. Journal of Online Learning \& Teaching, 9(4).

Carver, L., Todd, C., Hahn, K., \& Mukherjee, K. (2013). Students' perceptions of the effect of flipping online classes using a synchronous interactive online tool. Creative Education, 4(7), 126-129.

Condon, C., \& Valverde, R. (2014). Increasing critical thinking in web-based graduate management courses. Journal of Information Technology Education: Research, 13, 178-191. Retrieved from http://www.jite.org/documents/Vol13/JITEv13ResearchP177-191Condon0354.pdf

Drago, W., Peltier, J., \& Sorensen, D. (2002). Course content or the instructor: Which is more important in on-line teaching? Management Research News, 25(6/7), 69-83.

Ekstrom, J., Gorka, S., Kamali, R., Lawson, E., Lunt, B., Miller, J., et al. (2005). The information technology model curriculum. Journal of Information Technology Education, 5, 343-361. Retrieved from http://jite.org/documents/Vol5/v5p343-361Ekstrom155.pdf

Fain, P. (2010). Hard times require better planning and more online offerings, speakers tell publicuniversity leaders. Chronicle of Higher Education. Retrieved from http://chronicle.com/article/HardTimes-Require-Better/125404/

Friday, E., Friday-Stroud, S. S., Green, A. L., \& Hill, A. Y. (2006). A multi-semester comparison of student performance between multiple traditional and online sections of two management courses. Journal of Behavioral and Applied Management, 8(1), 66-81.

Gowan, A., \& Reichgelt, H. (2010). Emergence of the information technology discipline. Computer, 43(7), $79-81$.

Hansen, D. E. (2008). Knowledge transfer in online learning environments. Journal of Marketing Education, 30(2), 93-105.

Herman, T., \& Banister, S. (2007). Face-to-face versus online coursework: A comparison of learning outcomes and costs. Contemporary Issues in Technology and Teacher Education, 7(4), 318-326.

Lapsley, R., Kulik, B., Moody, R., \& Arbaugh, J. (2008). Is identical really identical? An investigation of equivalency theory and online learning. Journal of Educators Online, 5 (1).

Lim, H. L. (2007). Community of inquiry in an online undergraduate information technology course. Journal of Information Technology Education, 6, 153-169. Retrieved from http://www.jite.org/documents/Vol6/JITEv6p153-168Lim258.pdf

Lunt, B. M., Lawson, E. A., Goodman, G., \& Helps, R. (2002). Designing an IT curriculum: The results of the first CITC conference. Proceedings of the 2002 American Society for Engineering Education. American Society for Engineering Education. 
Mayadas, F. A., Bourne, J., \& Bacsich, P. (2009). Online education today. Science, 323(5910), 85-89.

Murray, M., Perez, J., Geist, D., \& Hedrick, A. (2012). Student interaction with online course content: Build it and they might come. Journal of Information Technology Education: Research, 11, 126-140. Retrieved from http://www.jite.informingscience.org/documents/Vol11/JITEv11p125140Murray1095.pdf

Newman, A., \& Hermans, C. (2008). Breaking the MBA delivery mould: A multi-group international MBA/practitioner virtual collaborative project. Marketing Education Review, 18(1), 9-14.

Ng, K. C. (2007). Replacing face-to-face tutorials by synchronous online technologies: Challenges and pedagogical implications. International Review of Research in Open and Distance Learning, 8(1), 115 .

Reichgelt, H., Lunt, B., Ashford, T., Phelps, A., Slazinski, E., \& Willis, C. (2004). A comparison of baccalaureate programs in information technology with baccalaureate programs in computer science and information systems. Journal of Information Technology Education, 3, 19-34. Retrieved from http://jite.org/documents/Vol3/v3p019-034-098.pdf

Senn, G. (2008). Comparison of face-to-face and hybrid delivery of a course that requires technology skills development. Journal of Information Technology Education, 7, 267-283. Retrieved from http://www.jite.org/documents/Vol7/JITEv7p267-283Senn309.pdf

Simonson, M., Schlosser, C., \& Hansen, D. (1999). Theory and distance education: A new discussion. The American Journal of Distance Education, 13(1).

Tappert, C., \& Stix, A. (2011). Project management and assessment of distributed teams in an online capstone masters-level information technology course. Proceedings of the International Conference on e-Learning, 382.

Trevathan, J., \& Myers, T. (2013). Towards online delivery of process-oriented guided inquiry learning techniques in information technology courses. Journal of Learning Design, 6(2), 1-11.

Wagner, S. C., Garippo, S. J., \& Lovaas, P. (2011). A longitudinal comparison of online versus traditional instruction. MERLOT Journal of Online Learning and Teaching, 7(1), 68-73.

Webb, H., Gill, G., \& Poe, G. (2005). Teaching with the case method online: pure versus hybrid appraoches. Decision Sciences Journal of Innovative Education, 3(2), 223-250.

Weber, M. J., \& Lennon, R. (2007). Multi-course omparison of traditional versus web-based course delivery systems. Journal of Educators Online, 4(2).

Zhang, A., \& Aasheim, C. (2011). Academic success factors: An IT student perspective. Journal of Information Technology Education, 10, 309-331. Retrieved from http://www.jite.org/documents/Vol10/JITEv10p309-331Zhang962.pdf

\section{Biographies}

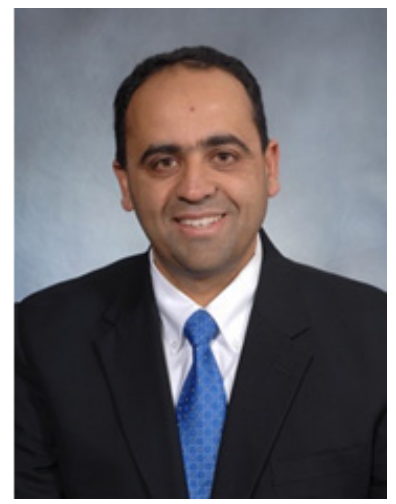

Hazem Said is an Associate Professor and Head of the School of Information Technology at the University of Cincinnati. He led a multiyear effort to transition nine different computing technology programs into Ohio's first ABET accredited Bachelor of Science in Information Technology. During that time Dr Said focused on excellence in teaching and service to the University and the region's IT workforce development. He established strong industry partnerships to foster different interdisciplinary programs for K-12, undergraduate and graduate IT education. His research is focused on comprehensive approaches to improving IT students' learning and success, while he continues to do applied research on the software development process and to foster interdisciplinary partnerships. 


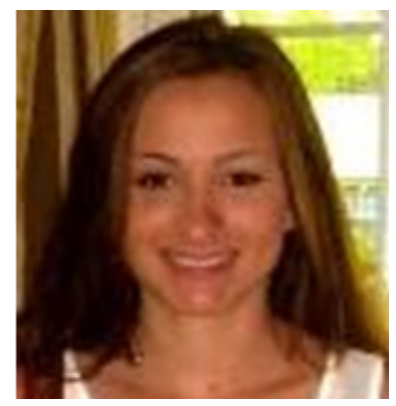

Lauren Kirgis is a senior at the University of Cincinnati studying Neuropsychology and Chemistry. She is particularly interested in the neural mechanisms underlying memory processes, architecture, history and culture. She is a member of the University Honors program and a recipient of the Cincinnatus University Scholarship.

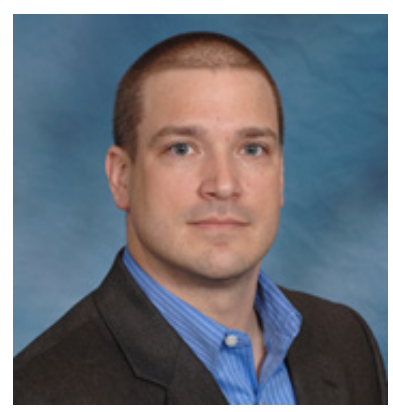

Brian Verkamp is an Assistant Dean for Technology Services at the College of Education, Criminal Justice and Human Services. He is an alumnus and an adjunct faculty in the School of Information Technology teaching online classes in Implication of Information Technology. $\mathrm{He}$ is the director of the Office of Innovative Technology and Learning Design where he provides leadership for instructional design support as well as technology support for over 70 different degree programs.

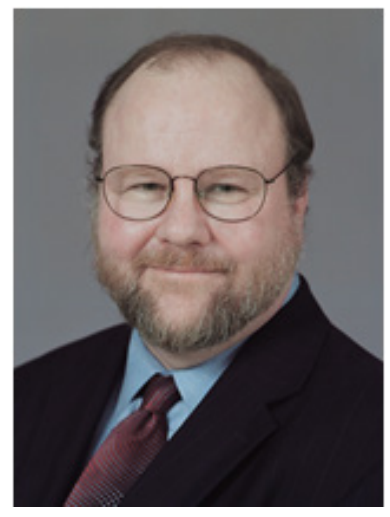

Lawrence J. Johnson is Dean and Professor, Early Childhood and Special Education, College of Education, Criminal Justice and Human Services at the University of Cincinnati. He serves as Executive Director of the Arlitt Child and Family Research and Education Center at the University of Cincinnati. Dean Johnson has published extensively, including 10 books, 33 chapters in books and 71 refereed journal articles. He has also served as the principal investigator or primary author of 200 grant proposals funded for a combined budget exceeding $\$ 100$ million, which have had an impact at the local, state, and national level. Dean Johnson has been recognized by multiple organizations for his contributions in education and by the states of Illinois, Alabama and Ohio. 